\title{
Corrigendum: New insight into spatial ecology of Griffon Vulture (Gyps fulvus) on the Balkans provides opportunity for focusing conservation actions for a threatened social scavenger
}

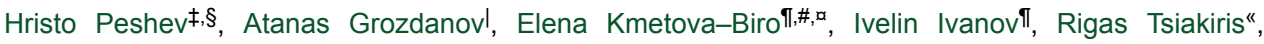

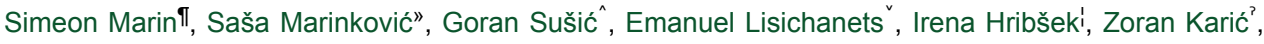 \\ Sven Kapelj ${ }^{\varsigma}$, Lachezar Bonchev ${ }^{\ddagger}$, Emilian Stoynov ${ }^{\ddagger}$ \\ ‡ Fund for Wild Flora and Fauna, 49 Ivan Mikhaylov Str., office 327, P.O.Box 78, www.fwff.org, pirin@fwff.org, Blagoevgrad, \\ Bulgaria \\ § South-West University „Neofit Rilski“, Faculty of Mathematics and Natural Sciences, Department of Geography, Ecology and \\ Environmental Protection, Blagoevgrad, Bulgaria \\ | Department of Zoology and anthropology, Faculty of Biology, Sofia University "St. Kliment Ohridski", 8 Dragan Tsankov Blvd, \\ zootribe@gmail.com, Sofia, Bulgaria \\ ף Green Balkans - 9 Stara Planina Str., www.greenbalkans.org, officesz@greenbalkans.org, Stara Zagora, Bulgaria \\ \# Austrian Ornithological Central, Vienna, Austria \\ a Central European University, Department of Environmental Sciences and Policy, Vienna, Austria, Vienna, Austria \\ « Ministry of Environment and Energy, Forestry Service of loannina, loaninna, Greece \\ "Department of Ecology, Institute for Biological Research "Siniša Stanković" - National Institute of Republic of Serbia, \\ University of Belgrade, Bulevar Despota Stefana 142, 11060, Belgrade, Serbia \\ ^Ornithological Station Rijeka, Croatian Academy of Sciences and Arts, Rijeka, Croatia \\ Nature Conservation Association - AQUILA, Kavadarci, Republic of North Macedonia \\ I Natural History Museum of Belgrade, Njegoseva 51, Belgrade, Serbia Birds of Prey Protection Foundation, Bulevar despota \\ Stefana 142, Belgrade, Serbia \\ ? Birds of Prey Protection Foundation, Bulevar despota Stefana 142, Belgrade, Serbia \\ ${ }^{\natural}$ Association BIOM, Zagreb, Croatia
}

Corresponding author: Hristo Peshev (hristopeshev.eu@gmail.com)

Academic editor: Pavel Stoev

Received: 31 Aug 2021 | Accepted: 01 Sep 2021 | Published: 01 Sep 2021

Citation: Peshev H, Grozdanov A, Kmetova-Biro E, Ivanov I, Tsiakiris R, Marin S, Marinković S, Sušić G, Lisichanets E, Hribšek I, Karić Z, Kapelj S, Bonchev L, Stoynov E () Corrigendum: New insight into spatial ecology of Griffon Vulture (Gyps fulvus) on the Balkans provides opportunity for focusing conservation actions for a threatened social scavenger.

(c) Peshev $\mathrm{H}$ et al. This is an open access article distributed under the terms of the Creative Commons Attribution License (CC BY 4.0), which permits unrestricted use, distribution, and reproduction in any medium, provided the original author and source are credited. 


\section{Corrigendum}

This is a corrigendum of the article Peshev et al. (2021). Due to a software malfunction during the data processing, the values in Table 4, columns 4-5 are incorrect. The correct values are given here in Table 1.

Table 1.

Correct values for Table 4, columns 4-5.

\begin{tabular}{|l|l|l|}
\hline Vulture key zone/ Country & $\begin{array}{l}\text { Area used by vutures, 50\% core } \\
\text { area, } \mathrm{km}^{2}\end{array}$ & $\begin{array}{l}\text { Area used by vutures, 95\% Home } \\
\text { range, } \mathrm{km}^{2}\end{array}$ \\
\hline Alpo - Adriatic, Austria/ Italy/ Croatia & 144.45 & 3229.01 \\
\hline Western Serbia, Serbia & 100.43 & 2356.42 \\
\hline Vrachanski Balkan Nature Park, Bulgaria & 28.8 & 1197.21 \\
\hline Eastern Balkan Mountain, Bulgaria & 13.76 & 626.3 \\
\hline $\begin{array}{l}\text { Struma and Vardar Velleys, Bulgaria/ North } \\
\text { Macedonia }\end{array}$ & 107.3 & 3704.92 \\
\hline Eastern Rhodopes, Bulgaria/ Greece & 236.54 & 4705.91 \\
\hline Western Greece, Greece & 220.45 & 4387.11 \\
\hline
\end{tabular}

The correct values must be taken in consideration also in the text, describing the results of Table 3 in the section "Defining vulture key zones in the Balkan Peninsula 1-7" and in the Abstract, where the sum of these values is included and is now corrected as follows: "The total home range $95 \%$ area of the Griffon Vulture population on the Balkans was estimated at $20,206.88 \mathrm{~km}^{2}$ and the $50 \%$ core area at $851.73 \mathrm{~km}^{2}(\mathrm{n}=48) . "$

In the section "Defining vulture key zones in the Balkan Peninsula" corrections were made in the numbers of tracked birds as follows: 3. Vrachanski Balkan Nature Park - corrected to "based on the location data of a total of 12 tracked birds.)"; 4. Eastern Balkan Mountain corrected to "based on the location data of a total of 9 tracked birds)"; 6 . Eastern Rhodopes - corrected to "(based on the location data of a total of 22 tracked birds)";

\section{References}

- Peshev H, Grozdanov A, Kmetova-Biro E, Ivanov I, Stoyanov G, Tsiakiris R, Marin S, Marinković S, Sušić G, Lisichanets E, Hribšek I, Karić Z, Kapelj S, Bonchev L, Stoynov E (2021) New insight into spatial ecology of Griffon Vulture (Gyps fulvus) on the Balkans provides opportunity for focusing conservation actions for a threatened social scavenger. Biodiversity Data Journal 9 https://doi.org/10.3897/bdj.9.e71100 